\title{
Regional Innovation and Investment Development in Conditions of Cluster Industrial Policy
}

\author{
A.V. Zastupov, ${ }^{1, *}$ \\ *Corresponding author: oiler79@mail.ru. \\ ${ }^{1}$ Samara State University of Economics, Samara, Russia
}

\begin{abstract}
An important task of the modern industrial policy of the region is to ensure the growth of the industrial component on the basis of innovation and investment development of industries. Issues of postcrisis development and economic growth in conditions of limited resources were considered. The effectiveness of industrial policies in the region needs to be matched to real innovation and investment opportunities. On the basis of the analysis, a model on the formation of directions of innovation and investment development of industrial policy of the Samara region was developed. The relationship between the factors of innovative development of enterprises and the level of investment activity in the industrial sector of the region has been determined. The study identified problems of formation of innovation and investment potential of industrial enterprises of the region and ways to solve them.
\end{abstract}

Keywords: Industrial policy, innovation, investment, resources, factor, region.

\section{Introduction}

Today, the problems of post-crisis development and economic growth in the context of limited resources are becoming increasingly pressing for the regions. The main task becomes to ensure the growth of the industrial component on the basis of innovation and investment development of the region's economy. It is necessary to change the structure of the economy, organizational and institutional environment, increase the share of industries with high added value, formation of innovation and investment environment in modern market conditions.

\section{Problem Statement}

In the current economic conditions, the problem of increasing the innovation and investment development of the region's economy, the development of appropriate scientific-based approaches and mechanisms to increase the innovative potential and investment activity of industrial enterprises becomes an important problem.

Problems devoted to issues of increasing innovative potential of enterprises of the region, growth of innovative activity of industrial enterprises, formation of cluster industrial policy of the region were considered in the works of domestic and foreign authors - B.Y. Tatarskich [3], A.V. Streltsov [3], F. Phillips [1], T. Andersson [2], C. Ketels [4], G. Duranton [5], A. Gawer [8] etc.

According to the analytical review on this issue, the issues of increasing innovation and investment activity of industrial enterprises in the region, as well as organizational and economic aspects of innovation and investment development of industrial industries of the region have not been sufficiently investigated.

\section{Research Questions}

This study considers theoretical and practical aspects of innovation and investment development of industrial industries of the region, issues of increasing the efficiency of industrial policy of the region through the cluster model of development of the regional economy. The application of theoretical and methodological provisions and practical recommendations of the study will make it possible to make informed decisions in the field of innovation and investment development of industry enterprises.

The practical significance of the study is that the main results can be used by state and municipal authorities and the business community in the development of priority directions for improving the efficiency of the innovative business environment and innovation and investment development of the region.

Further research in this area will allow to expand the understanding of the possibilities of applying theoretical and methodological provisions and practical recommendations in the sphere of increasing investment activity of industrial enterprises and innovation potential of the region as a whole. Research should focus on the results achieved in the development of the region's economy. 


\section{Purpose of the Study} study:

The following objectives and objectives have been identified in accordance with the issues and questions of the

- Explore industrial policy as a factor for economic growth in the region.

- To define directions and approaches to innovation and investment development of industry of the region in modern economic conditions.

- To develop a model of selection of priorities of innovation and investment development of the industrial complex of the region.

- To form proposals of an organizational and economic nature to improve the proposed forms and approaches of innovative and investment development of the industrial economy in the region.

\section{Research Methods}

\subsection{Methods of research}

The following methods were used during the study: theoretical (analysis, classification, concretization, synthesis); diagnostic (factor analysis, modeling, prediction, expert assessment method); empirical (observation, comparison, generalization).

\subsection{Experimental Study Base}

The experimental base of the study was a complex of enterprises of the industrial sector of the economy of the Samara region.

\subsection{Study Stages}

The study of the problem was carried out in 2 stages:

1. Theoretical:

- Research of industrial policy, investment and innovation potential of the economy of the Samara region.

2. Practical:

- Identification of directions and approaches to innovation and investment development of the region's industry in modern economic conditions;

- Development of a model of selection of priorities for innovation and investment development of the industrial complex of the region;

- Formation of proposals of organizational and economic character to improve the proposed forms and approaches of innovative and investment development of industrial economy in the region.

\section{Findings}

At present, the development of the Russian economy as a whole is oriented towards measures related to the improvement of market institutions, the increase of openness of the economy and the reduction of state participation in the economy in the long term. These provisions and the rejection of measures of the so-called selective industrial policy are based on the following arguments:

1. Increasing the level of industrial technological development dynamics. This causes a sharp narrowing of the horizons of economic and technological forecasts.

2. Growth of resource and technological needs of modern society. This creates greater complexity in technological solutions and increases the overall level of uncertainty.

The use of industry priorities is characteristic of traditional industrial policy options. It is rejected because of inefficiency and because of the high uncertainty in the innovative digital economy [1]. According to this view, the traditional model of concentration of material, labour and other resources by the State for its own purposes is now losing its relevance. This is due to the acceleration of economic processes and the short planning horizon. Today, in conditions of digitalization of the economy, the market and business are able to determine points of potential growth better than the state. This will be helped by factors of borrowing experience and own innovations, based on investment and innovation in the economy.

At the same time, the possibility of the state carrying out a strategy of catching-up growth is not rejected. However, emphasis is placed on the creation of institutional prerequisites and conditions for macroeconomic growth. Development priorities are proposed to be linked to institutions rather than industries. It should be noted that during the 1990s the economies of most developed countries and the well-being of their populations grew quite intensively on an innovative basis. In Russia, gross domestic product, levels of industrial and agricultural production have almost halved, 
and the level of real incomes of the population has significantly decreased. By comparison, the maximum fall in gross domestic product in the US during the crisis of the 1930s did not exceed 32 percent [2].

Of course, the importance of institutional reforms cannot be underestimated. Moreover, the extent and nature of the impact of the State on the industrial development of a country depends on the characteristics of its institutional structure and the level of development of the most important elements (industrial associations, financial institutions). This is also determined by the level of development of formal and informal coordination mechanisms for these institutions.

State industrial policy is able to detect and eliminate the negative side effects of harsh monetary conditions. It also allows to redirect priorities of financial support from inefficient enterprises to more economically sustainable economic entities, to focus efforts on priority areas of production. The experience of economic development in modern market conditions suggests that the development of production in market conditions without active structural industrial policies can lead to the loss of available technological advantages. Such a structural industrial policy should be based on an individual approach to certain sectors of the economy [3, p. 86-87].

Years of reform have led to the deindustrialization of many of the country's industries. Economic growth in recent years has not ensured the restoration of pre-reform production in many of the most important sectors that determine the trajectory of the country's economic development. There has been a sharp increase in services, especially in trade and financial areas. In addition, the previous structure of services proved to be inadequate to the requirements of modern market economy. The rapid emergence and growth of such activities as banking, insurance, notary, brokerage and others did not correspond to the current level of industrial development.

Therefore, when the problems of ensuring post-crisis development and economic growth in the context of limited resources arise, the main task becomes to ensure the growth of the industrial component on the basis of innovation and investment development.

Let us turn to the regional issue of economic growth. It is obvious that the adoption of industrial policies is more relevant for industrialized regions with a high share of manufacturing industries, compared to the national economy [4]. The need to overcome the consequences of the crisis, deindustrialization in these regions, modernization and transition to a strategy of innovative development of existing enterprises and creation of competitive advantages in domestic and foreign markets can explain this fact.

Regional aspects of industrial policy should be described. Here it is important to note that within its framework the most important patterns of placement of productive forces must be observed, namely:

- Economically viable and efficient placement of industrial production, taking into account the influence of economic, resource, geographical and environmental factors;

- Comprehensive regional economic development of economic entities and the economy of the region as a whole;

- A rational territorial division of labor between regions and within their territories, taking into account the regional aspects of the interest to attract personnel and the creation of high human capacity;

- Achievement of high rates of socio-economic development of the regions, provision of the necessary number of high-productivity jobs and infrastructure development [5].

In addition, restoring the manageability of the economy, changing its structure, changing the organizational and institutional environment, increasing the share of high-value-added industries, forming an innovation and investment environment in modern market conditions is essential.

In this regard, the methods of industrial policy should be consistently applied to a specific stage of development of the real sector of the economy: information, macroeconomic regulation, institutional and other. In order to achieve the effectiveness of industrial policies in the region, it is also necessary to rank them over time, according to the stages of economic development. It is also necessary to specialize methods by activity and to relate them to real innovation and investment opportunities.

We will analyze the economic state and trends of industrial development dynamics in the Samara region over the last ten years.

It can be noted at once that in 10 years significant changes have taken place in the structure of investments. The share of investments in mining, production and distribution of electricity, gas and water has increased significantly. The share of investments in many traditionally leading industrial industries in the Samara region has significantly decreased. These are food production, chemical production, machine-building. The latter aspect appears to be a particularly negative trend, as mechanical engineering held a leading position in the economy of the Samara region (table 1).

Table 1. Structure of investments by type of economic activity industrial economy of Samara region for 2008-2017.

\begin{tabular}{|l|c|c|c|c|}
\hline $\begin{array}{l}\text { Structure of investments by type of economic } \\
\text { activity, percentage }\end{array}$ & 2008 & 2011 & 2014 & 2017 \\
\hline Mining (petrochemical cluster) & 9.4 & 10.7 & 8.9 & 12.2 \\
\hline Processing productions & 24.4 & 24.3 & 44.1 & 39.7 \\
\hline $\begin{array}{l}\text { from them: } \\
\text { food products production }\end{array}$ & 3.3 & 2.1 & 1.0 & 0.9 \\
\hline $\begin{array}{l}\text { Production of coke and petroleum products } \\
\text { (petrochemical cluster) }\end{array}$ & 4.2 & 6.8 & 27.2 & 24.4 \\
\hline
\end{tabular}




\begin{tabular}{|l|c|c|c|c|}
\hline Chemical production & 3.7 & 4.7 & 2.4 & 3.6 \\
\hline $\begin{array}{l}\text { Machinery and equipment production } \\
\text { (machine building cluster) }\end{array}$ & 0.9 & 1.4 & 1.8 & 0.5 \\
\hline $\begin{array}{l}\text { Production of electric equipment, electrical and } \\
\text { optical equipment (space cluster) }\end{array}$ & 1.0 & 0.5 & 0.5 & 0.4 \\
\hline $\begin{array}{l}\text { Production of vehicles and equipment } \\
\text { (automobile cluster) }\end{array}$ & 4.8 & 5.4 & 8.8 & 10.8 \\
\hline Electricity, gas and water production and distribution & 7.4 & 11.4 & 8.0 & 13.6 \\
\hline
\end{tabular}

Source: Author.

For comparison, in 1990 more than $40 \%$ of all volume of investment into the industry of the Samara region were the share of mechanical engineering and metal working (machine-building, machine-tool constructing clusters) (table 2).

Table 2. Structure of investments by industry of the Samara region in 1990.

\begin{tabular}{|l|l|}
\hline Investment structure by industry & Value (percentage) \\
\hline Power industry & 5.0 \\
\hline Fuel industry & 20.1 \\
\hline Chemical and petrochemical industries & 9.9 \\
\hline Mechanical engineering and metalworking & 41.1 \\
\hline Construction materials industry & 3.7 \\
\hline Weaver's industry & 0.8 \\
\hline Food industry & 3.6 \\
\hline
\end{tabular}

Source: Author.

Dynamics of indicators of table 1 shows that the prevailing share of investments is the share of the processing productions. However, in the processing productions they are distributed extremely unevenly. Practically for all studied period, behind a small exception, the main volume of investment goes to the enterprises of two types of activity production of coke and oil products, chemical production (a petrochemical cluster), production of vehicles and the equipment (an automobile cluster). Extremely low share of investments into other industrial types of economic activity - machine-building, machine-tool constructing, space clusters of the region attracts attention.

Thus, on the basis of the above, it is possible to form certain methodological recommendations for the formation and implementation of the investment industrial policy of the region (figure 1).

Measures of rigid character:
- Formation of priority criteria;
- Selection of hierarchy of priority industries;
- Identification of priority industries;
- Concentration of investments in selected
priority areas;
- Establishment of directed investment
regulators;
- Identification of the need for personnel in
priority areas;
- Training for industrial development priorities

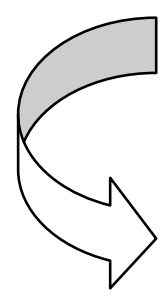

Innovation and investment development

Forming of investment programs and innovation projects within industrial clusters and their investment providing
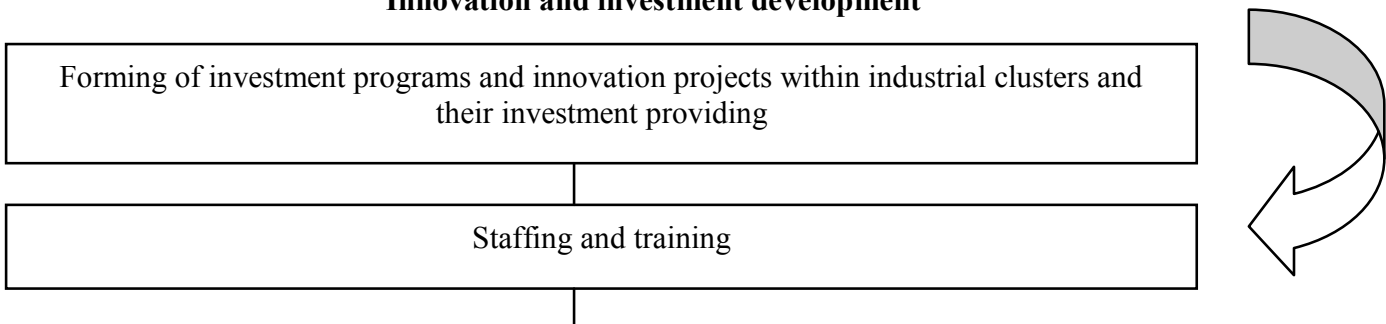

Evaluation of cluster industrial policy performance and development of innovative directions for its improvement

Fig. 1. Formation of directions of innovation and investment development of industrial policy of the region (Source: Author). 
Thus, an integrated approach is necessary for the formation and implementation of directions of innovation and investment development of industry of the region. It is capable of creating an innovative product in the industrial sector and attracting investors to finance innovation in industrial industries. Such cooperation and integration of directed actions in ensuring innovation and investment development is most fully and effectively implemented through large industrial forms of organization of production processes at the regional level. Such development is based on the reproductive interaction of economic entities and industrial sectors of the economy of the region as a whole. Such form which is the most effectively answering to the listed parameters is formation of industrial clusters in the region [6, $\mathrm{p}$. 354-355]. Industrial clusters accumulate in themselves traditional approaches in management of region economy. They are based on industry accessory of economic entities and represent modern cross-industry forms of innovation and investment development. In this case the character and depth of the created cross-industry communications provide high-quality innovative development of the territory with attraction of investments into economy of the region and formation of the new markets.

The most important task of innovative development of the industrial sector of the economy is to ensure innovative demand by enterprises of the industrial sector of the economy of the region.

The task of supporting and stimulating innovation becomes ineffective in the face of insufficient demand for innovative resources in the economy. Relevance is lost in the implementation of innovative projects and the creation of innovative products. In this case, investments are aimed at stimulating innovative demand and are becoming ineffective or are becoming very long-term. This can lead to a loss of innovation in the product or technology and inefficient spending of funds. Any innovation requires lengthy research and development. As a rule, the time for its development is much longer than the time for modernization of production facilities. Therefore, the demand for industrial innovation will always be greater than their supply in a normally functioning market economy [7, p. 562-563].

The analysis which is carried out above should be added. It is necessary to consider the state of affairs with innovative development of the enterprises of the industry of the region. Innovations along with investments represent one more major reserve of growth of economy and development of the enterprises of petrochemical, space, machinebuilding, automobile clusters of the region. At the same time, the most important indicator is the volume of innovative goods, works, services by type of economic activity. Prospects for innovative development of industrial enterprises allow to estimate costs of technological innovation (table 3 ).

Table 3. Costs of technological innovation by type of innovation activity in Samara region for 2007-2017.

\begin{tabular}{|l|c|c|c|c|}
\hline $\begin{array}{l}\text { Costs of technological innovation by type of } \\
\text { innovation activity, million rubles (in } \\
\text { comparable prices) }\end{array}$ & 2007 & 2010 & 2013 & 2017 \\
\hline In total & 9430.9 & 11475.4 & 41840.2 & 32877.9 \\
\hline $\begin{array}{l}\text { including: } \\
\text { Research and development of new products, } \\
\text { services and methods }\end{array}$ & 1511.6 & 1494.6 & 13092.6 & 11874.6 \\
\hline Acquisition of machinery and equipment & 5506.9 & 4529.6 & 18042.5 & 9752.1 \\
\hline Acquisition of new technologies & 8.5 & 153.3 & 198.2 & 109.8 \\
\hline Acquisition of software & 121.3 & 231.4 & 133.6 & 241.4 \\
\hline Other types of preparation & 1463.3 & 549.7 & 1827.6 & 5657.8 \\
\hline Production Design & 383.4 & 1816.1 & 2374.6 & 3710.9 \\
\hline Staff education and training & 115.1 & 68.8 & 137.7 & 86.4 \\
\hline Market researches & 9.8 & 5.1 & 45.3 & 36.2 \\
\hline Other costs of technological innovation & 557.0 & 5337.4 & 9933.5 & 9597.3 \\
\hline
\end{tabular}

Source: Author.

From table 3 it is possible to note that dynamics of volume of innovative products - in general positive, despite the imposed economic sanctions on number of industries of the Russian Federation in 2014. In this regard some reduction of indicators by types of innovative activity in 2017 is observed. Rather high innovative level of the issued goods can be noted on production of vehicles in automobile cluster of economy of the region. If in 2010 the share of innovations in products of automobile cluster (production of vehicles and the equipment) made 72.7 percent, then in 2013 the share of innovations has already made 63 percent, in $2017-60.7$ percent.

Thus, the presented these loudspeakers of volume of innovative products correspond to indicators of dynamics of the volume of investment by the types of economic activity of economy of the Samara region given in table 1 . This shows that the factor of innovative development of enterprises and the region is determined by the level of investment activity in the industrial sector. 
Currently, the largest amount of financing for the development of knowledge-intensive technologies is required for the entire cycle of scientific and technical activities, namely:

1) carrying out targeted scientific missions and training specialists on the basis of the leading universities of the country;

2) organization of research work in research institutes, universities, research organizations and scientific and technical centers of leading enterprises;

3) carrying out a scientific and technical examination of the performance of the technology level for monitoring the rating of critical technologies in industrial industries;

4) organization of targeted training of research engineers on innovative management and forecasting of scientific and technological progress, implementation of strategic programs in enterprises of industrial industries of the region.

Forming of strategy of the innovative development of the industrial sector of economy of the region should be based on comprehensive study of the possible directions it implementation. It is necessary to adhere to a certain model of rules on its forming and further implementation in the conditions of educated industrial clusters [8]. First of all, it is necessary to carry out the complex analysis of a status and development of industrial economy in the region. Further, it is necessary to define and structure the created trends and problems, to carry out component analysis, to reveal the key priority dynamic industries which are the driver of growth of economy in the region and are capable to create additional points of growth.

The stage of studying of innovation investment potential of economy of the explored region should become an important stage in carrying out such analysis. For the purpose of implementation of effective industrial policy the choice of priorities of development of the industry of the region around which the innovation industrial clusters should be formed will be result of an analytical research. The choice of the key industries capable to become the engine of development of economy of the region, and the subsequent support of such industries at the level of regional and federal authorities should not contradict industrial policy in general. It is a number of the directions of support of medium and small business, improvement of the normative and legal legislation, infrastructure development, development of cooperation, information environment, providing preferential terms (see fig. 1). Moreover, these measures will allow not only to provide effective development of key industries in the region, but also to create additional opportunities of growth which will be able to provide effective dynamics of sustainable development of allied industries and productions.

Speaking about the peculiarities of development of industrial enterprises in conditions of limited investment resources, it is possible to note the lack of available innovative and investment resources for innovation and investment development of the economy of the region. In this regard, the business community, state and municipal authorities face the most important task of launching innovative industries and producing innovative products, but also of fully involving the scientific community in this process, creating the necessary laboratories and experimental stations, where development and experimental scientific developments on the creation of innovative technologies and products will be constantly carried out.

Thus, the innovation and hi-tech productions created in the region on the basis of the created industrial clusters become a basis in implementation of the innovation and investment strategy of development of industrial policy. They demand providing in the region not only investment resources, but also high scientific potential. Improvement of organizational and administrative mechanisms of innovation and investment development, involvement in the created industrial clusters of the scientific organizations and educational institutions of secondary vocational and higher education are necessary. It can be fully implemented through forming and development of the innovation industrial clusters in the region with participation of the innovation centers and technological parks in the field of high technologies.

\section{Conclusion}

The article presents the main results, conclusions and recommendations on the problems of increasing the investment activity of industrial enterprises and improving the innovative potential of the region in the context of clustering the economy.

Scientific results of the study fundamentally complement the existing approach to the problem of increasing innovation and investment activity of enterprises of the industrial sector and efficiency of industrial policy of the region as a whole. At the same time, the instruments of cluster approach of innovation and investment development of the region's economy play a key role in this process.

\section{References}

1. F. Phillips, H. Linstone, Key ideas from a 25-year collaboration at technological forecasting \& social change. Technological Forecasting \& Social Change, 105, 158-166 (2016).

2. T. Andersson, S. Schwaag-Serger, J. Sörvik, E. Wise, Cluster policies whitebook (IKED - International Organisation for Knowledge Economy and Enterprise Development, Malmö, 2004). 
3. A.V. Zastupov, A.V. Streltsov, B.Y. Tatarskikh, V.B. Poluyanov, H.M. Murtazova, Petrochemical cluster as the engine of the region's economic development. International Journal of Economic Perspectives, 10(3), 83-93 (2016).

4. C. Ketels, Recent research on competitiveness and clusters: What are the implications for regional policy? Cambridge Journal of Regions, Economy and Society, 6(2), 269-284 (2013). DOI: 10.1093/cjres/rst008.

5. G. Duranton, California dreamin: The feeble case for cluster policies. Rev. Econ. Anal., 3(1), 3-45 (2011).

6. A.V. Zastupov, Investment development of enterprises of industrial clusters. In S. Ashmarina, M. Vochozka (Eds.), Sustainable Growth and Development of Economic Systems. Contributions to Economics (pp. 349-358). Cham: Springer (2019). DOI: 10.1007/978-3-030-11754-2_25.

7. A.V. Zastupov, Innovation activities of enterprises of the industrial sector in the conditions of economy digitalization. In S. Ashmarina, A. Mesquita, M. Vochozka (Eds.), Digital Transformation of the Economy: Challenges, Trends and New Opportunities. Advances in Intelligent Systems and Computing, 908 (pp. 559-569). Cham: Springer (2019). DOI: 10.1007/978-3-030-11367-4_55.

8. A. Gawer, Bridging differing perspectives on technological platforms: Toward an integrative framework. Research Policy, 43(7), 1239-1249 (2014). 